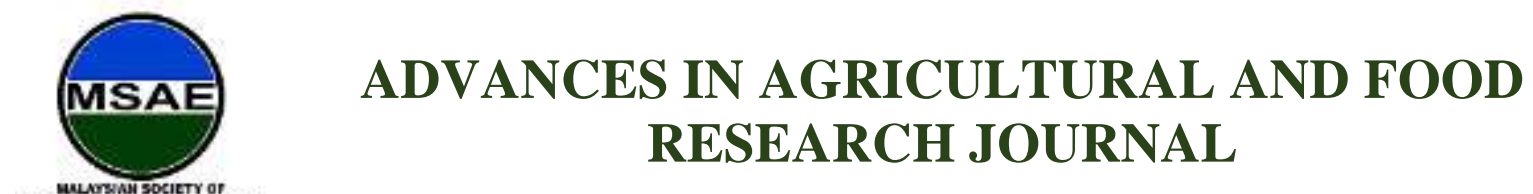

HH PUBLISHER

Original Research Article

\title{
Properties of Grain Corn During Short Term Storage in Tropical Ambient Temperature
}

Sharifah Hafiza Mohd. Ramli ${ }^{1 *}$, Yahya Sahari ${ }^{1}$, Nurfarhana Abdullah ${ }^{2}$, Siti Rajwani Hashim ${ }^{2}$, Ahmad Fadhlul Wafiq Abdul Rahman ${ }^{1}$, Mohd Shahrir Azizan ${ }^{1}$, Saiful Azwan Azizan ${ }^{1}$, Faewati Abd Karim¹, Amir Redzuan Shamsulkamal ${ }^{1}$, Azmirredzuan Sani ${ }^{1}$

${ }^{1}$ Engineering Research Centre, MARDI Headquarters, Persiaran MARDI - UPM, 43400 Serdang, Selangor shhafiza@mardi.gov.my, ybs@mardi.gov.my, shahrir@mardi.giv.my, asazwan@mardi.gov.my, wafiq@mardi.gov.my, amir@mardi.gov.my, fae@mardi.gov.my, miewan@mardi.gov.my

${ }^{2}$ Commercial \& Business Research Centre, MARDI Headquarters, Persiaran MARDI - UPM, 43400 Serdang, Selangor, Country, farhana@mardi.gov.my, rajwani@mardi.gov.my

*Corresponding author: Sharifah Hafiza Mohd. Ramli, Engineering Research Centre, MARDI Headquarters, Persiaran MARDI - UPM, 43400 Serdang, Selangor; shhafiza@ mardi.gov.my

Abstract: Grain corn in nature possesses a tendency to absorb and release moisture even during storage. Grain respiration will lead to fungal growth, consequently mycotoxin development and decreased nutritional components. Storage in tropical weather like Malaysia, in which the temperature is constantly hot throughout the year (temperature 23$33^{\circ} \mathrm{C}$, with relative humidity around $81 \%$ ) will promote further spoilage to the stored grain corn. Therefore, this paper discussed the properties of grain corn during three months of storage in a Malaysian weather setting. Grain corn with the initial moisture content of $12.5 \pm$ $0.02 \% \mathrm{MC}$ bagged in the; a) woven polypropylene jumbo bags, b) woven propylene $40 \mathrm{~kg}$ bag and c) plastic sealed container was stored in two different storage facilities located in MARDI for three months. The grain corn after three months of storage showed a consistent water activity, a darkening value in Chroma index, within the permissible limit of fungal growth and exhibits insect pest development of two major species of Coleoptera family. Grain corn is considered safe after three months of storage because low aflatoxin levels have been found, but the physical structure has been compromised due to insect pest infestations.

Keywords: grain corn; storage; animal feed

Received: $26^{\text {th }}$ February 2021

Received in revised form: $7^{\text {th }}$ May 2021

Accepted: $24^{\text {th }}$ May 2021

Available Online: $2^{\text {nd }}$ July 2021

Citation: Mohd Ramli SH, Sahari Y, Abdullah N, et al. Properties of grain corn during short term storage in tropical ambient temperature. Adv Agri Food Res J 2021; 2(2): a0000210. https://doi.org/10.36877/aafrj.a0000210 


\section{Introduction}

The introduction of grain corn cultivation in Malaysia is mainly to reduce the gap in the import balance trade of animal feed and consequently lessen the country's dependency on import trade. Malaysia was reported to import 2.5 tonnes of grain corn in 2000, and the trend showed an increasing pattern, where as in 2015, the imported bill reached 4.0 million tonnes (Aziz, 2017; Reddy \& Salleh, 2011). Following this, the Malaysian government under the Ministry of Agriculture and Food Industries (MAFI) and its agencies has undertaken efforts to introduce grain corn cultivation in Malaysia. The effort also was implemented as part of strengthening food security apart from curbing the stress and instability of the world supply and foreign exchange (MARDI, 2017). The technology covers the whole value chain; from primary to secondary processing involving plantation, harvesting, and postharvest handling of the grain corn.

The postharvest handling of grain corn includes two major critical processes such as drying and storage of grain corn. As drying is of importance to control the moisture content of the grain after harvest, the ultimate goal of storage of grain is to ensure there is no significant negative occurrence at the quality levels during storage to guarantee the best quality obtained by the end-users. The three important variables during storage of grain include the storage duration, grain temperature and moisture condition which are sufficient to predict the storage condition of the grain (Fleurat-Lessard, 2002). The general principle of grain storage is that most of the grain quality is affected by the interaction of these variables to the ecological storage condition.

Malaysia, located in the tropical weather belt, in which the temperature is constantly hot throughout the year (temperature $23-33^{\circ} \mathrm{C}$, with relative humidity around $81 \%$ ) will promote further spoilage to the stored grain corn. Insect invasion of grain storage is associated with different geographical locations and weather conditions (Afsah-Hejri et al., 2013)

Rashad et al. (2003) have presented the common storage mould at more than $81 \%$ relative humidity (RH) with moisture content (MC) around 15-18\% comprised of Aspergillus flavus, Parssiticus and Penicillium spp. Aspergillus flavus was common in temperate and tropical weather (Kumar \& Kalita, 2017). Reddy and Salleh (2011) established that the possibility of mould and mycotoxin contamination in grain corn feed was due to inappropriate storage during production, hence, recommended proper storage structures for grain corn in Malaysia. Kumar and Kalita (2017) also highlighted the major postharvest losses of maize was due to insufficient proper storage of the grain. The highest postharvest losses of corn might be contributed during storage, with calculated losses of around 2-5\% (Dass, 2019). However, to the authors' knowledge, there are still limited reports on the storage of grain corn in this geographical region, especially Malaysia since the cultivation of grain corn in Malaysia is still at farmers' scale. Therefore, this paper reports on some 
properties of the grain corn during short term (three months) storage of grain corn at ambient temperature in Malaysia.

\section{Materials and Methods}

\subsection{Sample Description}

Grain corn samples, GWG 888 variety were procured from a local supplier; Green World Genetics Sdn. Bhd. One tonne of grain corn was stored in a conventional woven polypropylene, $(\mathrm{PP}) 40 \mathrm{~kg}$ bag $(58 \times 96 \mathrm{~cm})$ and stored at Engineering Research Centre Workshop, MARDI Serdang, at Location A as a control experiment (A1). Another 1-tonne of grain corn in a woven polypropylene bag $(58 \times 96 \mathrm{~cm})$ was stored at Location $\mathrm{B}$, Engineering Research Centre Workshop (A2), MARDI Serdang. For comparison, 1-tonne grain corn was stored in a woven polypropylene jumbo bag (top duffle, bottom spout) ( $95 \times$ $95 \mathrm{~cm}$ ) in Location A (C1) and another $150 \mathrm{~kg}$ grain corn was placed in a sealed container $(49.5 \times 96 \mathrm{~cm}, \phi 39.5 \mathrm{~cm})$ at Location A (C2) as an alternative hermetic technology.

\subsection{Temperature Monitoring During Storage}

Temperature monitoring during the different storage was logged using a data logger (Extech 42270, Malaysia) for their environmental conditions. The data loggers were set to record with hourly intervals for temperature and RH during a week of logging period.

\subsection{Grain Properties during Storage}

Grain properties, such as water activity $\left(\mathrm{a}_{\mathrm{w}}\right), \mathrm{MC}$, proximate analysis, and colour changes were tested every month for a total of three months. The MC of the samples was measured using a grain moisture analyser (mini GAC Plus 2500, Dickey John, USA). Approximately $380 \mathrm{~g}$ of grain corn samples were put in the cartridge of the moisture analyser and the reading was measured. Water activity, $\left(\mathrm{a}_{\mathrm{w}}\right)$ of grain corn sample was measured using a water activity meter (Labmaster-aw 1119971, Novasina, Switzerland). Proximate analysis such as protein (Kjeldahl method), fat (Soxhlet extraction), moisture and ash (oven method) were done according to the AOAC method. The carbohydrate content is calculated by subtracting the sum of moisture ash protein \& fat from $100 \%$.

Colour changes were measured using chromameter (Model CR 401, Konica Minolta, Japan) represented by the tristimulus Hunter $L * a * b$ coordinates (Itle, 2009). The variations of the $L * a * b$ coordinates were calculated using equations 1-3, the total colour difference, $\Delta E$ was calculated based on equation 4 and the colour intensity, chroma index is calculated as in equation 5 below as described by (Goneli et al., 2018).

$$
\begin{aligned}
& \Delta L=L_{(t)}-L_{\left(t_{0}\right)} \\
& \Delta a=a_{(t)}-a_{\left(t_{0}\right)}
\end{aligned}
$$




$$
\begin{aligned}
& \Delta b=b_{(t)}-b_{\left(t_{0}\right)} \\
& \Delta E=\sqrt{\Delta L^{2}+\Delta b^{2}+\Delta b^{2}} \\
& C r=\sqrt{a^{2}+b^{2}}
\end{aligned}
$$

$\Delta L=$ Lightness coordinates difference, $L *=$ lightness value

$t_{0}=$ beginning of the storage period, $t=$ storage period, days,

$\Delta a=$ redness or greenness difference, $a *=$ redness or greenness value

$\Delta b=$ yellowness or blueness difference, $b *=$ yellowness or blueness value

$\Delta E=$ Total colour difference, $\mathrm{Cr}=$ chroma index redness or greenness difference

\subsection{Fungal Analysis}

For the microbiological analysis, $50 \mathrm{~g}$ of each grain corn sample was mixed with 450 $\mathrm{mL}$ sterile Ringers solution and homogenised by shaking vigorously. Serial dilutions were prepared up to $10^{-5}$. For each dilution, $0.1 \mathrm{~mL}$ was transferred to malt extract agar (MEA, $\mathrm{pH}$ 3.5 acidified with $10 \%$ tartaric acid) using the surface spread plate technique. The plates were then incubated at $32^{\circ} \mathrm{C}$ for 72 hours for total fungi count.

\subsection{Insect Assessment}

Grain corn samples were processed for insect assessment after the existence of insects was noticed. An amount of $0.5 \mathrm{~kg}$ of sub-samples from different storage location was poured on a tray and the samples were then sifted using siever (Laboratory Test Sieves, England) sizes of 7, 10 and $25(2.8 \mathrm{~mm}, 2 \mathrm{~mm}$ and $0.71 \mathrm{~mm}$, respectively) following the method by Danso et al. (2017). The collected insect was frozen and then counted. The species identification was done by an expert entomologist.

\section{Results}

The condition of the grain was examined from the initial point and continuously monitored by monthly analysis. The initial condition of grain was the prime condition in predicting the shelf life of grain (Fleurat-Lessard, 2002). The initial moisture content of the grain is the minimum criterion in predicting the permissible storage for the grain corn. The guidelines for safe storage condition for grain corn is around $12-15 \%$ moisture content dry basis (FAO, 2011). For the grain corn in this experiment, the initial moisture content is 12.5 $\pm 0.02 \% \mathrm{MC}$, with no aflatoxin detected. 
Dass (2019) mentioned that grain corn at $13-14 \%$ moisture content is commonly stable until the third months of storage. They may require technological intervention, to prolong the storage time, whether biologically, physically or by chemical means.

\subsection{Temperature During Storage}

Location A1 has an average temperature of $29.3^{\circ} \mathrm{C}$ and average $\mathrm{RH}, 63.4 \%$, while A2 has an average of $28.1^{\circ} \mathrm{C}$ with $65.5 \% \mathrm{RH}$. The ambience in the sealed containers, $\mathrm{C} 2$ was at $26.7^{\circ} \mathrm{C}, 64.1 \% \mathrm{RH}$. The temperature profile of the stored grain corn was depicted in Figure 1. The highest temperature was found at location $\mathrm{A} 1$, at $29.3^{\circ} \mathrm{C}$ and the highest humidity was found at location $\mathrm{A} 2,65.5 \% \mathrm{RH}$. The ambient conditions at the three different locations had a slight variation; however, it does not differ much.

a)

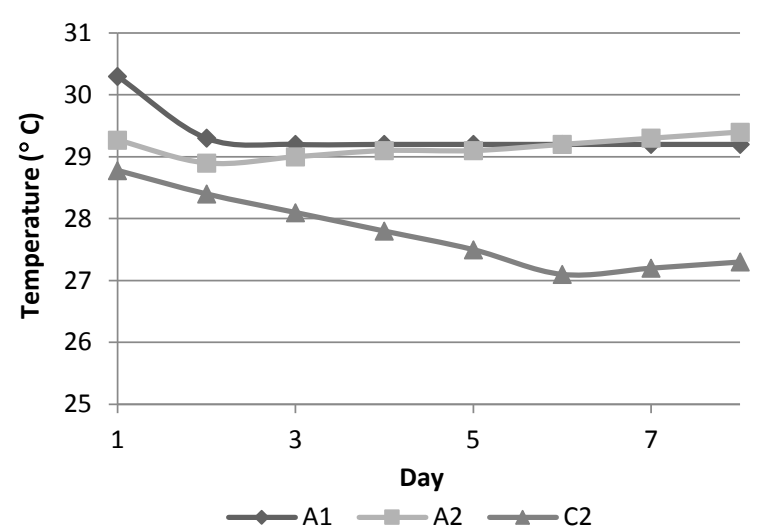

b)

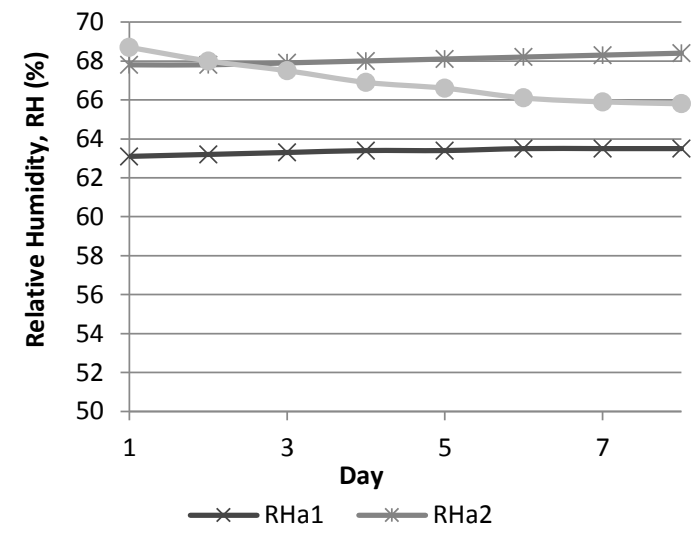

Figure1. a) average temperature profiles of stored grain during a week storage b) average relative humidity at a different storage location.

\subsection{Physical Properties Of Grain (Nutritional Analysis)}

\subsubsection{MC and proximate composition}

The nutritional composition of grain corn variety GWG888 is shown in Table 1. Initially, the MC of the sample was $12.5 \pm 0.2 \%$, and the corn was highest with the carbohydrate content, $72.1 \pm 0.4 \%$. The MC and other composition of carbohydrate, protein and ash remained unchanged throughout the storage period with exception of the fat component. The fat component exhibited a decreasing trend throughout the storage months as shown in Figure 2. However, no effect on the storage location and packaging material were noticed. 
Table 1. Proximate Analysis of GWG888 grain corn variety.

\begin{tabular}{ccccccc}
\hline Storage & Duration & $\begin{array}{c}\text { Moisture } \\
\text { Content, MC } \\
(\boldsymbol{\%})\end{array}$ & Carbohydrate & Protein & Fat & Ash \\
& & & & & \\
\hline Initial & Initial & $12.5 \pm 0.2$ & $72.1 \pm 0.4$ & $9.8 \pm 0.1$ & $4.1 \pm 0.4$ & $1.6 \pm 0.3$ \\
\hline A1 & & $12.7 \pm 0.1$ & $68.7 \pm 0.5$ & $9.6 \pm 0.3$ & $7.1 \pm 0.4$ & $1.9 \pm 0.2$ \\
A2 & \multirow{2}{*}{1 months } & $12.7 \pm 0.4$ & $70.3 \pm 0.3$ & $9.5 \pm 0.2$ & $5.7 \pm 0.4$ & $1.8 \pm 0.1$ \\
C1 & & $12.2 \pm 0.1$ & $70.7 \pm 0.8$ & $9.7 \pm 0.1$ & $5.5 \pm 0.7$ & $1.9 \pm 0.2$ \\
C2 & & $12.8 \pm 0.1$ & $72.6 \pm 1.5$ & $9.5 \pm 0.4$ & $5.2 \pm 0.8$ & $1.8 \pm 0.2$ \\
\hline A1 & & $12.7 \pm 0.1$ & $73.0 \pm 0.8$ & $9.5 \pm 0.2$ & $3.4 \pm 0.1$ & $1.8 \pm 0.2$ \\
A2 & \multirow{2}{*}{2 months } & $12.5 \pm 0.3$ & $72.8 \pm 1.0$ & $9.2 \pm 0.2$ & $3.5 \pm 0.4$ & $1.6 \pm 0.1$ \\
C1 & & $12.3 \pm 0.1$ & $70.7 \pm 1.1$ & $9.5 \pm 0.3$ & $3.6 \pm 0.6$ & $1.6 \pm 0.1$ \\
C2 & & $12.5 \pm 0.3$ & $72.7 \pm 0.6$ & $9.6 \pm 0.5$ & $3.5 \pm 0.6$ & $1.7 \pm 0.1$ \\
\hline
\end{tabular}

$\mathrm{A} 1=$ woven PP bag location $\mathrm{A}, \mathrm{A} 2=$ woven bag PP location $\mathrm{B}$

$\mathrm{C} 1=\mathrm{PP}$ jumbo bag location $\mathrm{A}, \mathrm{C} 2=$ sealed containers location $\mathrm{A}$

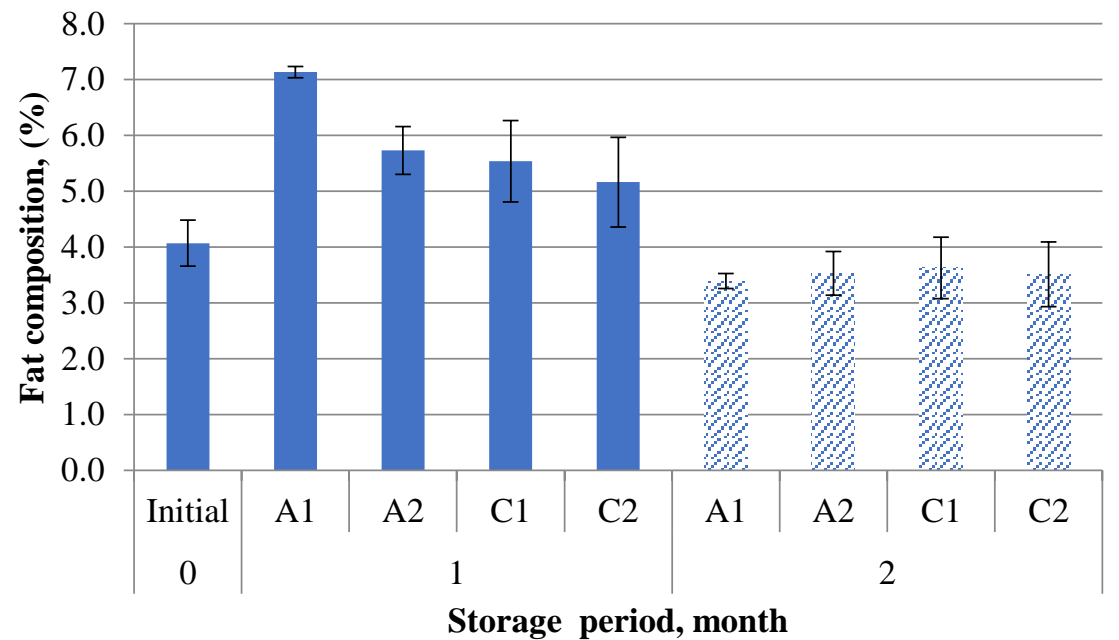

Figure 2. The fat composition of grain corn during storage.

\subsubsection{Water activity, $a_{w}$}

Grain corn GWG888 showed a consistent water activity throughout the three months of storage regardless of the temperature, $\mathrm{RH}$ and packaging type as shown in Table 2 . The water activity for the grain corn was in the range of 0.5-0.6, which appears to be the optimum for the growth of storage fungi, xerophilic fungi at the water activity $\leq 0.95$. 
Table 2. Mean water activity of grain corn samples.

\begin{tabular}{ccc}
\hline Storage & Duration & Mean water activity, $\mathbf{a}_{\mathbf{w}}$ \\
\hline Initial & Initial & $\mathbf{0 . 5 2} \pm \mathbf{0 . 0 1}$ \\
\hline $\mathrm{A} 1$ & & $0.537 \pm 0.01$ \\
$\mathrm{~A} 2$ & \multirow{2}{*}{ months } & $0.527 \pm 0.01$ \\
$\mathrm{C} 1$ & & $0.519 \pm 0.01$ \\
$\mathrm{C} 2$ & & $0.514 \pm 0.01$ \\
\hline $\mathrm{A} 1$ & & $0.555 \pm 0.01$ \\
$\mathrm{~A} 2$ & \multirow{2}{*}{ months } & $0.511 \pm 0.01$ \\
$\mathrm{C} 1$ & & $0.494 \pm 0.01$ \\
$\mathrm{C} 2$ & & $0.501 \pm 0.01$ \\
\hline A1 & & $0.505 \pm 0.01$ \\
A2 & & $0.492 \pm 0.01$ \\
C1 & 3 months & $0.515 \pm 0.01$ \\
C2 & & $0.516 \pm 0.01$
\end{tabular}

\footnotetext{
$\mathrm{A} 1=$ woven $\mathrm{PP}$ bag location $\mathrm{A}$,

$\mathrm{A} 2=$ woven bag PP location $\mathrm{B}$

$\mathrm{C} 1=\mathrm{PP}$ jumbo bag location $\mathrm{A}$,

$\mathrm{C} 2=$ sealed containers location $\mathrm{A}$
}

\subsubsection{Colorimeter}

Qualitatively, the colour of the grain maintained as yellow throughout the storage period. The results of the colour changes of the grain were also measured quantitatively using the chroma meter throughout the three months of storage, as shown in Figure 3 and Table 3. The values of $L *$ (range 50.5-62.3), $a *(0.45-11.4)$ and $b *(20.0-30.8)$ found in this experiment were different from the work done by Saenz et al. (2020) with the values of $L *$ (range 46.4-54.6), $a *(6.5-10.5)$ and $b *(14.7-20.2)$. The calculated chroma index value was similar to the value of $b *$ was also found in this study (Table 3 ). 


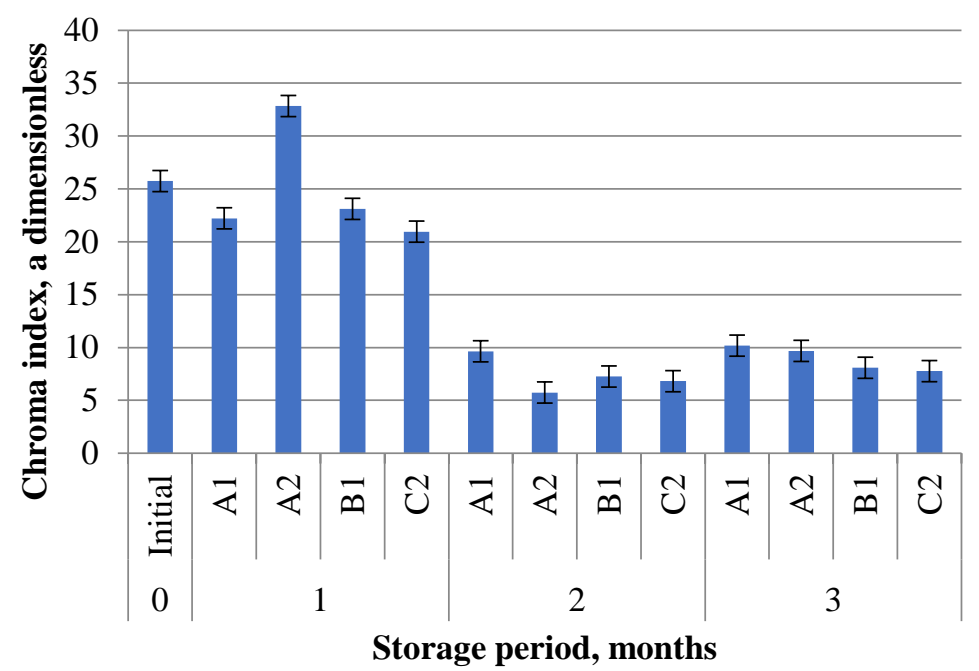

Figure 3. Chroma index, $\mathrm{Cr}$ of the grain corn during storage.

\subsection{Fungal Analysis}

Visually, no mouldy grain was found. Fungal analysis was carried out to obtain the correlation between the fungal and the aflatoxin producing mould. Of all corn grains samples tested monthly during the storage period up to 3 months, the total mould count ranged from $1.60 \times 10^{3} \mathrm{CFU} / \mathrm{g}$ to $7.20 \times 10^{4} \mathrm{CFU} / \mathrm{g}$ as shown in Table 4 . In experimental storage condition $\mathrm{A} 1$ and $\mathrm{C} 2$, the count decreased throughout the storage period, whereas A2 and $\mathrm{C} 1$ showed a small increase in 2-month storage then decreased, thus can be considered not significant.

Table 4. Total mould count (CFU/g) observed on acidified MEA agar of corn grain stored in four conditions (A1, A2, C1, C3) for 3 months.

\begin{tabular}{ccccc}
\hline Storage & \multicolumn{4}{c}{ Mean CFU/g x 10 } \\
\hline Duration & Initial & 1 month & 2 months & 3 months \\
\hline A1 & 36.5 & 47.5 & 25.5 & 9.1 \\
A2 & 68.5 & 2.00 & 5.25 & 1.6 \\
C1 & 72.0 & 8.20 & 14.0 & 3.4 \\
C2 & 72.0 & 22.5 & 12.0 & 3.0 \\
\hline A1= woven PP bag location A, \\
A2= woven bag PP location B \\
C1= PP jumbo bag location A, \\
C2= sealed containers location A \\
\hline
\end{tabular}


Insect infestation exhibits as early as a month of storage, though, it was highly visible after three months of storage. Therefore, the insect assessment was carried out during the third month of storage. The number of insects per sieving was shown in Table 5. During the storage period, the two major insects found was from the family of Coleoptera which was identified as Sitophilus Zeamais and Oryzaephilus Surinamensis were found in the woven sacks and jumbo bag.

The highest insect count was found in A2, grain corn packed in $40 \mathrm{~kg}$ woven polypropylene bags with 189 insects in $500 \mathrm{~g}$ samples, followed by samples stored in location A, also packed in $40 \mathrm{~kg}$ woven polypropylene bags. The insect count for grain corn at location A either in a jumbo bag or the grain corn packed in woven polypropylene bags has a similar count. The least insect count was from grain corn placed in sealed containers, with 27 insects per $500 \mathrm{~g}$ samples.

Table 5. The insects count in the samples of grain corn.

\begin{tabular}{cc}
\hline Storage & Insect count/500 g \\
\hline A1 & 74 \\
A2 & 189 \\
C1 & 73 \\
C3 & 27 \\
\hline A1= woven PP bag location A, \\
A2= woven bag PP location B \\
C1= PP jumbo bag location A, \\
C2= sealed containers location A
\end{tabular}

The population of moth (Lepidoptera family) was also noted during storage in Location A1, however, it was not found during the sieving and count process. 
Table 3. The colour differences of the grain throughout the storage period.

\begin{tabular}{|c|c|c|c|c|c|c|c|c|c|}
\hline \multirow{2}{*}{ Month } & \multirow{2}{*}{ Sample } & \multicolumn{3}{|c|}{ Chroma Parameters } & \multicolumn{4}{|c|}{ Colour Difference } & \multirow{2}{*}{$\begin{array}{c}\text { Chroma } \\
\text { Index } \\
\text { Cr }\end{array}$} \\
\hline & & $\boldsymbol{L} *$ & $a *$ & $\boldsymbol{b} *$ & $\Delta \boldsymbol{L}$ & $\Delta a$ & $\Delta b$ & $\Delta \boldsymbol{E}$ & \\
\hline 0 & Initial & $\begin{array}{c}53.58 \pm \\
4.35\end{array}$ & $\begin{array}{c}6.09 \pm \\
2.54\end{array}$ & $\begin{array}{c}25.01 \pm \\
3.26\end{array}$ & & & & & 25.74 \\
\hline \multirow{4}{*}{1} & A1 & $\begin{array}{c}62.35 \pm \\
0.00\end{array}$ & $\begin{array}{c}5.26 \pm \\
0.00\end{array}$ & $\begin{array}{c}21.59 \pm \\
0.01\end{array}$ & 8.77 & $\begin{array}{c}- \\
0.83\end{array}$ & 3.42 & 9.45 & 22.22 \\
\hline & $\mathrm{A} 2$ & $\begin{array}{c}60.84 \pm \\
0.01\end{array}$ & $\begin{array}{c}11.4 \pm \\
0.03\end{array}$ & $\begin{array}{c}30.8 \pm \\
0.02\end{array}$ & 7.26 & 5.31 & 5.79 & 10.69 & 32.84 \\
\hline & $\mathrm{C} 1$ & $\begin{array}{c}54.14 \pm \\
0.01\end{array}$ & $\begin{array}{c}10.45 \pm \\
0.05\end{array}$ & $\begin{array}{c}28.8 \pm \\
0.02\end{array}$ & 0.56 & 4.36 & 3.79 & 5.80 & 30.64 \\
\hline & $\mathrm{C} 2$ & $\begin{array}{c}57.51 \pm \\
0.00\end{array}$ & $\begin{array}{c}6.41 \pm \\
0.03\end{array}$ & $\begin{array}{c}19.96 \pm \\
0.02\end{array}$ & 3.93 & 0.32 & $\begin{array}{c}- \\
5.05\end{array}$ & 6.41 & 20.96 \\
\hline \multirow{4}{*}{2} & $\mathrm{~A} 1$ & $\begin{array}{c}50.51 \pm \\
1.18\end{array}$ & $\begin{array}{c}2.95 \pm \\
0.52\end{array}$ & $\begin{array}{c}22.35 \pm \\
1.05\end{array}$ & -3.07 & $\begin{array}{c}- \\
3.14\end{array}$ & $\begin{array}{c}- \\
2.66\end{array}$ & 5.14 & 22.54 \\
\hline & $\mathrm{A} 2$ & $52.43 \pm 6.79$ & $\begin{array}{c}2.17 \pm \\
3.20\end{array}$ & $\begin{array}{c}21.35 \pm \\
2.16\end{array}$ & -1.15 & $\begin{array}{c}- \\
3.92\end{array}$ & $\begin{array}{c}- \\
3.66\end{array}$ & 5.49 & 21.46 \\
\hline & $\mathrm{C} 1$ & $\begin{array}{c}51.70 \pm \\
1.89\end{array}$ & $\begin{array}{c}2.68 \pm \\
2.21\end{array}$ & $\begin{array}{c}21.44 \pm \\
2.16\end{array}$ & -1.88 & 3.41 & $\begin{array}{c}- \\
3.57\end{array}$ & 5.29 & 21.61 \\
\hline & $\mathrm{C} 2$ & $\begin{array}{c}57.50 \pm \\
3.75\end{array}$ & $\begin{array}{c}0.45 \pm \\
1.77\end{array}$ & $\begin{array}{c}21.39 \pm \\
1.59\end{array}$ & 3.92 & $\begin{array}{c}- \\
5.64\end{array}$ & $\begin{array}{c}- \\
3.62\end{array}$ & 7.77 & 21.39 \\
\hline \multirow{4}{*}{3} & A1 & $\begin{array}{c}58.95 \pm \\
4.98\end{array}$ & $\begin{array}{l}1.2 \pm \\
1.69\end{array}$ & $\begin{array}{c}22.97 \pm \\
0.55\end{array}$ & 5.37 & $\begin{array}{c}- \\
4.89\end{array}$ & $\begin{array}{c}- \\
2.04\end{array}$ & 7.54 & 23.00 \\
\hline & $\mathrm{A} 2$ & $\begin{array}{c}58.02 \pm \\
4.81\end{array}$ & $\begin{array}{c}2.34 \pm \\
1.99\end{array}$ & $\begin{array}{c}23.52 \pm \\
1.16\end{array}$ & 4.44 & $\begin{array}{c}- \\
3.75\end{array}$ & $\begin{array}{c}- \\
1.49\end{array}$ & 6.00 & 23.64 \\
\hline & $\mathrm{C} 1$ & $\begin{array}{c}57.21 \pm \\
2.15\end{array}$ & $\begin{array}{c}1.92 \pm \\
1.01\end{array}$ & $\begin{array}{c}23.41 \pm \\
1.04\end{array}$ & 3.63 & $\begin{array}{c}- \\
4.17\end{array}$ & $\begin{array}{c}- \\
1.60\end{array}$ & 5.76 & 23.49 \\
\hline & $\mathrm{C} 2$ & $\begin{array}{c}54.57 \pm \\
1.38\end{array}$ & $\begin{array}{c}4.18 \pm \\
0.98\end{array}$ & $\begin{array}{c}25.11 \pm \\
1.37\end{array}$ & 0.99 & $\begin{array}{c}- \\
1.91\end{array}$ & 0.10 & 2.15 & 25.46 \\
\hline \multicolumn{10}{|c|}{$\begin{array}{l}\mathrm{A} 1=\text { woven } \mathrm{PP} \text { bag location } \mathrm{A}, \\
\mathrm{A} 2=\text { woven bag PP location } \mathrm{B} \\
\mathrm{C} 1=\mathrm{PP} \text { jumbo bag location } \mathrm{A}, \\
\mathrm{C} 2=\text { sealed containers location } \mathrm{A}\end{array}$} \\
\hline
\end{tabular}




\section{Discussions}

\subsection{Temperature during Storage}

Grain degradation is expected to be tenth times higher in a hot and humid environment (Dass, 2019). Theoretically, the relationship between these environmental conditions and the storability of the grain will affect germination and insect heating (FAO, 2011). The temperature and $\mathrm{RH}$ which are abiotic factors are important as these factors will govern the possibility of insect, fungal growth and consequently the aflatoxin development.

\subsection{Physical Properties of Grain}

\subsubsection{MC and proximate composition}

The trend of the decreasing fat component during storage, regardless of the storage condition was in agreement with the findings by many others (Garbaba et al., 2017; Stefanello et al., 2015). The decreasing fat content in different seeds species may be due to the chemical instability of the fat component itself (Stefanello et al., 2015). Garbaba et al. (2017), on the other hand, linked the loss of fat content in maize to storage pest damage, which also happening in the site storage study.

The MC and other composition of carbohydrate, protein and ash remained unchanged throughout the storage period, which might indicate that the storage does not lead to decrease in nutritional composition. Fungal growth has been associated to a decrease in nutritional composition during maize storage (Garbaba et al., 2017; Rashad et al., 2003). In this study, the condition can be linked as limited fungal growth as visually no mouldy grain were found and the aflatoxin reading is within permissible limit.

\subsubsection{Water activity, $a_{w}$}

Apart from the ecological environment, the water activity of the grain is considered to be one of the key factors for fungal growth (Mannaa \& Kim, 2017). Water activity is the exact measurement of available water for fungal growth. Therefore, the results found in this study are in correlation with the fungal analysis, that there was mould count during the storage of the grain corn throughout the storage period.

\subsection{Colorimeter}

The Hunter scales determine the lightness, $L$ and chromaticity ( $a$ defines red/greenness, and $b$ defines yellow or blueness (Saenz et al., 2020). Furthermore, by determining the Chroma index, the shift in colouration could be confirmed. This index indicates the degree of decrease in the saturation of the grain usual colours, resulting in a more greyish hue (Goneli et al., 2018). The $L *$ coordinate indicates darkness or lightness of colour and ranges from black (0) to white (100), while the values of $a *$ and $b *$ indicate the 
colour direction $(+a *$ is the red direction, $-a *$ is the green direction, $+b *$ is the yellow direction and $-b *$ is the blue direction).

The different results of $L * a * b$ coordinates found in this study perhaps were because of the different genotype and environment that have affected the values of $L * a * b$ for corn kernel significantly (Saenz et al., 2020). The calculated Chroma index value similar to the value of $b *$ was also found by the others who studied the yellowness in the food products (Kljak et al., 2014). The Chroma index has shown a decreasing value since the first month of storage, except sample A2, however, later the Chroma index continued to decrease after the second and third months for all samples. The decreasing Chroma indicated a darkening colour of grain, which also similar to the other findings on grain, for instances, coffee and castor beans (Goneli et al., 2018).

Since grain corn is usually yellow, the coordinate b (yellowness) is the major interest in this analysis. The positive value of coordinate $b$ is in agreement with the yellowness colour of the grain. The positive value of $\Delta b$, indicates that the grain is more yellow than the standard, which is $t_{0}$. Only the value of samples A2 and C1 in the first month and C2 in the third month showed a positive value, while the rest of the samples showed negative $\Delta b$, indicating less yellow than the $t_{0}$.

\subsection{Fungal Analysis}

Mannaa and Kim (2017) reported that the tropical region is common with the growth of field fungi like the genera of Aspergillus, which is also an aflatoxin producing mould. Colonization by certain fungi like Fusarium sp. reduced the supply of nutrient available to other fungi as observed by Marın et al. (1998). This perhaps explained the decreased mould count in this study.

Identification of isolate fungi will give a better view of field fungus species occurrence and relation to the storage condition. Aflatoxin analysis carried out by commercial laboratory indicated that no aflatoxin was detected since the initial sample and it was predicted to be within the permissible limit of $50 \mathrm{ppb}$ (Aziz, 2017) after three months of storage based on the previous storage study (data not shown).

\subsection{Insect Assessment}

The inclination for the insect attack was also in agreement with Rashad et al. (2003) that $\mathrm{RH}$ of $70-80 \%$, and temperature of $25-30^{\circ} \mathrm{C}$ were found to be optimum for insect growth. The same insects were species found in this study, Sitophilus Zeamais and Oryzaephilus Surinamensis were also mentioned by Danso et al. (2017) and FAO (1994). Coleoptera and Lepidoptera are common insect pests in stored products and may be found in other types of grains like wheat, sorghum, paddy and rice (FAO, 1994). Though there was insect pest, smallholder farmers responded that the grain corn is still useful for feeding their 
poultry for direct consumption, provided some pre-treatment is performed such as immersing the grain corn in water for the removal of the insect pest.

The insect count indicated that the differences in atmosphere and packaging may have contributed to their growth. The least insect count in C2 was expected as the hermeticity atmosphere in the sealed containers was diminishing with oxygen which finally inhibits the activity of the insect. The alternative hermetic technology storage such as plastic bottles was also found to be effective in inhibiting insect growth in Mexico (Odjo et al., 2020). The highest insect count at location A2 may be suggested by the highest humidity in that location itself, 65.5\% RH promoting insect growth. Odjo et al. (2020) also found large numbers of live insect from maize stored in propylene bags in the tropical environment and concluded that this storage packaging type leads to high susceptibility to damage, including pest.

Overall, grain corn stored in bags with the initial moisture content of $12.5 \%$, stored at ambient storage showed a stable condition. Most parameters do not significantly affect storage condition for a duration of three months (Sbardelotto Di Domenico et al., 2015). However, it was necessary to have an overview of their quality before the critical months appear.

Storage in polypropylene bags is considered common amongst small farmers including Malaysia, Mexico (Odjo et al., 2020), Zambia (Taleon et al., 2017) and Ethiopia (Garbaba et al., 2017) as this is perceived to be a cost-effective storage method. Nevertheless, the failure of these types of storage in controlling the insect and fungi were also mentioned to have happened in the tropical region of Mexico and sub-Saharan African. Though the grain corn is safe, the quality is considered degraded due to the insect invasion.

\section{Conclusions}

Prediction for allowable storage time based on insect infestation found that the grain corn stored up to three months is stable, with the colours of the kernel maintained and no aflatoxin was detected. However, the physical structure was compromised due to minimal insect pest invasion. The grain quality degradation during storage is known for the interactions of set factors, abiotic - temperature, relative humidity, and biotics - water activity, genotype, and the substrates. Correlating the fungi growth with the aflatoxin producing mould is intriguing, to understand the ecological interaction with the growth. For short term storage, a periodical check on grain quality is feasible, while the same practice for long term storage requires some technological intervention, for instance, a different technology of hermetic storage, exposure to ozonation, radiation or thermal technology for the controlling of insect and mould growth. A computer-aided system compliment with a smart decision support system in larger storage facility such as silos will enhance the capability of the store manager to monitor the quality of stored grain corn. Diligent monitoring and prudent management are critical to supervise the possibilities of hazards and 
contaminants during the storage of grain corn. Maintaining hygiene and sanitation at the storage facilities is a good practice to control rodents and inhibit contamination from other sources. In short, storage of grain corn requires integrated management between store manager, postharvest engineers and pest management experts to maintain good quality grain corn.

Supplementary Materials: No supplementary materials.

Author Contributions: Sharifah Hafiza Mohd Ramli: conceptualization, methodology, data curation, writing and editing the manuscript, supervision and project administration. Yahya Sahari: conceptualization, methodology and supervision. Nurfarhana Abdullah: methodology, data analysis, writing and reviewing the manuscript. Siti Rajwani Hashim: methodology and analysis. Mohd Shahrir Azizan and Saiful Azwan Azizan: conceptualization and methodology. Ahmad Fadhlul Wafiq Abdul Rahman: storage manager, grain analysis and data curation. Faewati Abd Karim, Amir Redzuan Shamsulkamal and AzmirredzuanSani: grain analysis and data curation.

Funding: This work was funded by the fund of Sumber Kekayaan Baharu (SKB) under grant no KRM167.

Acknowledgements: The authors would like to express the utmost gratitude to Ms Zulaikha Mazlan for her kind contribution to the entomology work.

Conflicts of Interest: The authors declare no conflict of interest.

\section{References}

Afsah-Hejri, L., Jinap, S., Hajeb, P., Radu, S., \& Shakibazadeh, S. (2013). A Review on Mycotoxins in Food and Feed: Malaysia Case Study. Comprehensive Reviews in Food Science and Food Safety, 12(6), 629-651. doi:10.1111/1541-4337.12029

Aziz, A. A. (2017). Jagung Bijian Sebagai Sumber Makanan Haiwan Ternakan. Paper presented at the Seminar Pembangunan Industri Jagung Bijian Negara, Kemaman, Terengganu http://www.doa.gov.my/index/resources/aktiviti_sumber/sumber_awam/penerbitan/kertas_pembenta ngan/seminar_jagung bijian_2017/kertas_pembentangan4.pdf

Danso, J. K., Osekre, E. A., Manu, N., Opit, G. P., Armstrong, P., Arthur, F. H., . . Mbata, G. (2017). Moisture content, insect pests and mycotoxin levels of maize at harvest and post-harvest in the Middle Belt of Ghana. Journal of Stored Products Research, 74, 9. doi:10.1016/j.jspr.2017.08.007

Dass, W. S. (2019). Corn - Transportation and Storage Challenges. Paper presented at the Regional Corn Conference, Penang.

FAO. (1994) Grain storage techniques. Rome: Food and Agriculture Organization of the United Nations (FAO).

FAO. (2011). FAO Chapter 16. Grain crop drying, handling and storage. Retrieved from Rome: www.fao.org/3/i2433e/i2433e10.pdf

Fleurat-Lessard, F. (2002). Qualitative reasoning and integrated management of the quality of stored grain: a promising new approach. Journal of Stored Products Research, 38, 23.

Garbaba, C. A., Denboba, L. G., Ocho, F. L., \& Hensel, O. (2017). Nutritional deterioration of stored Zea mays L. along supply chain in southwestern Ethiopia: Implication for unseen dietary hunger. Journal of Stored Products Research, 70, 7-17. doi:10.1016/j.jspr.2016.10.004

Goneli, A. L. D., Corrêa, P. C., Oliveira, A. P. L. R., Hartmann Filho, C. P., \& Oba, G. C. (2018). Castor Beans Quality Subjected To Different Storage Temperatures And Periods. Engenharia Agrícola, 38, 361368.

Itle, R. A. a. K., E. A. (2009). Correlation Between L_a_b_Color Space Values and Carotenoid Content in Pumpkins and Squash (Cucurbita spp.). HortScience, 44(3), 5. 
Kljak, K., Grbeša, D., \& Karolyi, D. (2014). Reflectance colorimetry as a simple method for estimating carotenoid content in maize grain. Journal of Cereal Science, 59(2), 109-111. doi:10.1016/j.jcs.2013.12.004

Kumar, D., \& Kalita, P. (2017). Reducing Postharvest Losses during Storage of Grain Crops to Strengthen Food Security in Developing Countries. Foods, 6(1). doi:10.3390/foods6010008

Mannaa, M., \& Kim, K. D. (2017). Influence of Temperature and Water Activity on Deleterious Fungi and Mycotoxin Production during Grain Storage. Mycobiology, 45(4), 240-254. doi:10.5941/MYCO.2017.45.4.240

MARDI. (2017). Potensi Pengeluaran Jagung Bijian Negara. Paper presented at the Seminar Pembangunan Industri Jagung Bijian Negara, Kemaman, Terengganu. http://www.doa.gov.my/index/resources/aktiviti_sumber/sumber_awam/penerbitan/kertas_pembenta ngan/seminar_jagung_bijian_2017/kertas_pembentangan3.pdf

Marın, S., Sanchis, V., Arnau, F., Ramos, A., \& Magan, N. (1998). Colonisation and competitiveness of Aspergillus and Penicillium species on maize grain in the presence of Fusarium moniliforme and Fusarium proliferatum. International Journal of Food Microbiology, 45(2), 107-117.

Odjo, S., Burgueño, J., Rivers, A., \& Verhulst, N. (2020). Hermetic storage technologies reduce maize pest damage in smallholder farming systems in Mexico. Journal of Stored Products Research, 88, 101664. doi:10.1016/j.jspr.2020.101664

Rashad, A. S., Kurt, A. R., \& Bern, C. J. (2003). Effects of Deterioration Parameters on Storage of Maize. Paper presented at the Agricultural and Biosystems Engineering Conference Proceedings and Presentations.

Reddy, K. R. N., \& Salleh, B. (2011). Co-occurence of mould and mycotoxin in corn grains used for animal feed in Malaysia. Journal of Animal and Veterinary Advances, 10(5), 5.

Saenz, E., Abdala, L. J., Borrás, L., \& Gerde, J. A. (2020). Maize kernel color depends on the interaction between hardness and carotenoid concentration. Journal of Cereal Science, 91, 102901. doi:10.1016/j.jcs.2019.102901

Sbardelotto Di Domenico, A., Christ, D., Hashimoto, E. H., Busso, C., \& Coelho, S. R. M. (2015). Evaluation of quality attributes and the incidence of Fusarium sp. and Aspergillus sp. in different types of maize storage. Journal of Stored Products Research, 61, 59-64. doi:10.1016/j.jspr.2014.12.001

Stefanello, R., Londero, P. M. G., Muniz, M. F. B., Alves, J. S. a., \& Fischer, L. (2015). Chemical composition of landrace maize seeds stored under different conditions. International Food Research Journal, 22(3), 5 .

Taleon, V., Mugode, L., Cabrera-Soto, L., \& Palacios-Rojas, N. (2017). Carotenoid retention in biofortified maize using different post-harvest storage and packaging methods. Food Chem, 232, 60-66. doi:10.1016/j.foodchem.2017.03.158 